\title{
Efektivitas Ekstrak Daun Maja (Aegle marmelos (L) Corr) sebagai Larvasida Aedes aegypti
}

\section{The Effectiveness of Maja Leaves (Aegle marmelos) (L) Corr as Larvacide of Aedes aegypti}

\author{
Monica Puspa Sari ${ }^{1}$, Rina Priastini Susilowat? \\ ${ }^{1}$ Department of Parasitology, Faculty of Medicine, Ukrida, Jakarta \\ ${ }^{2}$ Department of Biology, Faculty of Medicine, Ukrida, Jakarta
}

KATA KUNCI KEYWORDS

ABSTRAK
Daun maja; Alkaloid; Mortalitas, Aedes aegypti

Maja Leaves; Alkaloid; Mortality; Aedes aegypti

Tanaman maja (Aegle marmelos), dikenal dengan "Bael atau Maja" dapat ditemukan disekitar kita, dapat dimanfaatkan sebagai larvasida alami karena ramah lingkungan dan relatif lebih aman bila dibandingkan dengan pestisida kimiawi yang mulai menimbulkan resistensi bagi hewan targetnya. Kandungan beberapa senyawa kimia seperti alkaloid, terpenoid dan tannin kemungkinan bersifat larvasida maka diperlukan untuk mengetahui apakah ekstrak daun maja menggunakan pelarut etil asetat dan etanol efektif dapat membunuh larva Aedes aegypti dengan berbagai konsentrasi yaitu 1\%;2\%; 4\%, $8 \%$; dan 16\%, dengan satu kelompok kontrol positif berupa temephos $1 \%$ dan kontrol negatif (tanpa paparan). Rancangan yang digunakan adalah rancangan acak lengkap (RAL) dengan ulangan sebanyak empat kali. Penelitian ini dilakukan di laboratorium penelitian fakultas kedokteran Universitas Kristen Krida Wacana (UKRIDA) dengan populasi larva sebanyak 25 larva per ulangan. Kematian larva Aedes aegypti diamati 24 jam setelah terpapar. Data yang diperoleh akan dianalisis menggunakan uji one way Anova dan dilanjutkan dengan uji beda nyata terkecil (uji BNT) untuk mengetahui apakah ada perbedaan yang bermakna antara temephos 1\% dengan ekstrak daun maja dosis bertingkat yang menggunakan pelarut etil asetat maupun etanol dalam berbagai konsentrasi. Hasil penelitian menunjukkan nilai LC50 dan LC90 dari pelarut etil asetat sebesar 2,03\% dan 3,04\%. Sedangkan nilai LC50 dan LC90 menggunakan pelarut etanol sebesar 4,12\% dan 10,82\%. Dapat disimpulkan bahwa ekstrak daun maja menggunakan pelarut etil asetat mempunyai aktivitas larvasida yang lebih tinggi dibandingkan menggunakan pelarut etanol. 
ABSTRACT Maja plant (Aegle marmelos) known as "Bael or Maja" can be found around us, can be used as a natural larvacide because it is environmentally friendly and is relatively safer when compared to chemical pesticides which begin to cause resistance for the target animals. The contents of some chemical compounds such as alkaloids, terpenoids, and tannins are likely to be larvacidal, so it is necessary to know whether the extract of maja leaves using ethyl acetate and ethanol solvents is effective against Aedes aegypti larvae with various concentrations of $1 \% ; 2 \% ; 4 \% ; 8 \%$; and $16 \%$, with one positive control group in the form of $1 \%$ temephos and negative controls (without exposure). The design used was a completely randomized design with four repetitions. This research was conducted in research laboratory of medical faculty of krida wacana with a larval population of 25 replicates. The death of Aedes aegypti larvae was observed 24 hours after exposure. The data obtained will be analyzed using one way anova test and followed by the smallest significant difference between 1\% temephos and multilevel maja leaf extract using ethyl acetate and ethanol solvents in various concentrations. The results showed that LC50 and LC90 values of ethyl acetate solvent were $2.03 \%$ and $3.04 \%$. While the LC50 and LC90 values used ethanol solvent of $4.12 \%$ and $10.82 \%$. It can be concluded that maja leaf extract using ethyl acetate solvent had higher larvacidal activity than using ethanol solvent.

Nyamuk merupakan serangga yang berperan sebagai vektor utama, dianggap sebagai hama dalam kesehatan masyarakat dan merupakan penyebab penyakit mematikan seperti malaria, demam berdarah, filariasis, dan ensefalitis virus diseluruh dunia dan memiliki 3000 spesies. Diperkirakan 1000 spesies yang dapat mentransmisikan berbagai penyakit pada manusia. (Borah, Kalita, Kar, \& Talukdar 2010; Dass \& Mariappan 2014; Reegan, Gandhi, Paulraj, \& Ignacimuthu 2015; Rueda 2008). DBD endemik hampir lebih dari 100 negara dan mengancam kesehatan 2.5 juta orang di dunia. (Borah et al., 2010) DBD merupakan penyakit yang disebabkan oleh virus dengue dengan empat serotipenya yaitu DEN-1, DEN-2, DEN3, DEN-4 dengan Aedes aegypti sebagai vektor utamanya. Nyamuk Aedes aegypti berkembang biak dengan baik pada wadah penampungan air bersih yang ada di dalam rumah seperti bak mandi, vas bunga, bak-bak penampung air dan aktif menggigit pada siang hari. (Hadi, Soviana, \& Gunandini 2013; WHO 2011) Indonesia merupakan wilayah endemis DBD dengan jumlah penderita dan luas penyebarannya yang semakin bertambah. 
Sebanyak 150.000 kasus DBD pernah dilaporkan di Indonesia pada tahun 2007 dimana 25.000 kasus dilaporkan terutama dari Jakarta dan Jawa barat dengan CFR 1\%. (World Health Organization 2009) Berdasarkan Data dari Direktorat Pencegahan dan Pengendalian Penyakit Tular Vektor dan Zoonotik, Kemenkes RI, pada tahun 2017 sejak Januari hingga Mei tercatat sebanyak 17.877 kasus dengan 115 kematian (Kemenkes RI 2017).

Pengendalian penyakit DBD, mulai dari gerakan $3 \mathrm{M}$, dan penggunaan insektisida sintetik telah dilakukan, namun hasil yang dicapai belum signifikan (Fahmi 2010). Pengendalian vektor menggunakan pestisida kimiawi seperti organoklorin, organofosfat, dan karbamat, perlu dipikirkan dampaknya terhadap kesehatan manusia dan dapat menimbulkan resistensi pada spesies nyamuk apabila pestisida tersebut digunakan secara terus-menerus (Ndione, Faye, Ndiaye, Dieye, \& Marie 2007; Reegan et al., 2015). Tanaman herbal merupakan tanaman yang banyak mengandung metabolit sekunder dan minyak esensial yang dapat dijadikan sebagai obat ataupun suatu produk yang berfungsi sebagai larvasida alami, misalnya tanaman maja (Aegle marmelos). Diketahui bahwa penggunaan tanaman herbal juga lebih aman, ekonomis, efektif dan mudah didapat (Beidokhti \& Prakash 2013). Buah maja (Aegle marmelos L) merupakan tanaman obat yang termasuk dalam famili Rutaceae yang tumbuh liar di hutan kering, dapat ditemukan di seluruh hutan Himalaya (Benni, Suresha, \& Jayanthi 2011; Reddy \& Urooj 2013). Sebagai tanaman perdu, kulit buah maja berwarna hijau dan keras, sedangkan daging buahnya berwarna putih, berbau harum dan rasanya manis. Di Indonesia, buah maja dapat kita jumpai terutama di dataran rendah seperti rawa-rawa maupun di lahan kering. Selain itu, buah maja juga tersebar di Asia tenggara dan Asia Selatan (Fatmawati 2015).

Penelitian ini lebih menggunakan daun maja daripada buah maja. Dari beberapa penelitian pendahuluan yang sudah dilakukan, diketahui bahwa daun maja lebih efektif bila dibandingkan dengan buah maja. Menggunakan bubuk daun maja, didapatkan nilai LC50 dan LC90 masing-masing sebesar 0,63\% dan 2,43\% (Sari, Susilowati, Parasitologi, Medicine, \& Christian, nd). Dapat disimpulkan bahwa dosis efektif dari daun maja yang dapat membunuh larva $A$. aegypti adalah sebesar 2,43\%. Oleh karena itu dilakukan penelitian untuk melihat apakah ekstrak daun maja efektif membunuh larva A. aegypti.

\section{BAHAN DAN CARA KERJA}

Penelitian ini merupakan penelitian eksperimental dengan menggunakan rancangan acak lengkap dengan perlakuan yang terdiri dari kontrol positif berupa abate $1 \%$, kontrol negatif (tanpa paparan), dan ekstrak daun maja 5 konsentrasi $(1 \%, 2 \%, 4 \%$, $8 \%$, dan 16\%) dengan 4 kali pengulangan. Penelitian dilakukan pada bulan November 2017 bertempat di Laboratorium Penelitian FK Ukrida. Populasi penelitian ini adalah larva instar III/IV A. aegypti yang diperoleh dari rearing telur A. aegypti dari Unit Kajian Pengendalian Hama Pemukiman (UKPHP) IPB. Sampel yang digunakan adalah 25 ekor larva per ulangan sesuai dengan acuan WHO. Pembuatan larutan uji yang berupa ekstrak ini menggunakan daun maja (Aegle 
marmelos). Daun maja dikeringkan dan diblender lalu ditimbang sebanyak $50 \mathrm{~g}$ daun maja dan dilarutkan menggunakan 3 pelarut berupa hexane, etil asetat dan etanol sebanyak $500 \mathrm{~mL}$ lalu dilakukan maserasi sebanyak $2 x$, dibiarkan dalam 24 jam dan dilakukan rotary evaporator sehingga didapatkan ekstraknya. Untuk mendapatkan konsentrasi $1 \%, 2 \%, 4 \%, 8 \%$ dan $16 \%$, pipet sebanyak $0,04 \mathrm{~mL}$ ekstrak daun maja dalam aquadest $500 \mathrm{~mL}$ dan dengan peningkatan dosis ekstrak $2 x$ nya setiap konsentrasi.

Telur A. aegypti diletakkan dalam bak plastik yang berisi air untuk pemeliharaan larva. Dalam masa perkembangannya, larva diberikan makan berupa pellet ikan. Pada saat larva telah mencapai instar III, larva dipindahkan ke dalam gelas plastik yang berisi ekstrak daun maja konsentrasi $1 \%, 2 \%, 4 \%, 8 \%$ dan $16 \%$, temephos $1 \%$ dan kontrol negatif dengan menggunakan pipet larva, kemudian dilakukan pengamatan kematian jumlah larva A. aegypti dalam 24 jam. Untuk menghitung data yang diperoleh dari penelitian ini menggunakan analisis One Way Anova. Bila pada uji One Way Anova diperoleh hasil yang bermakna, maka setelah itu dilakukan uji beda nyata terkecil (uji BNT) untuk mengetahui kelompok mana yang bermakna. Untuk menentukan nilai LC50 dan LC90 menggunakan uji probit.

\section{HASIL}

Berdasarkan hasil pengamatan pada mortalitas nyamuk A. aegypti diperoleh data seperti yang terlihat pada Gambar 1.

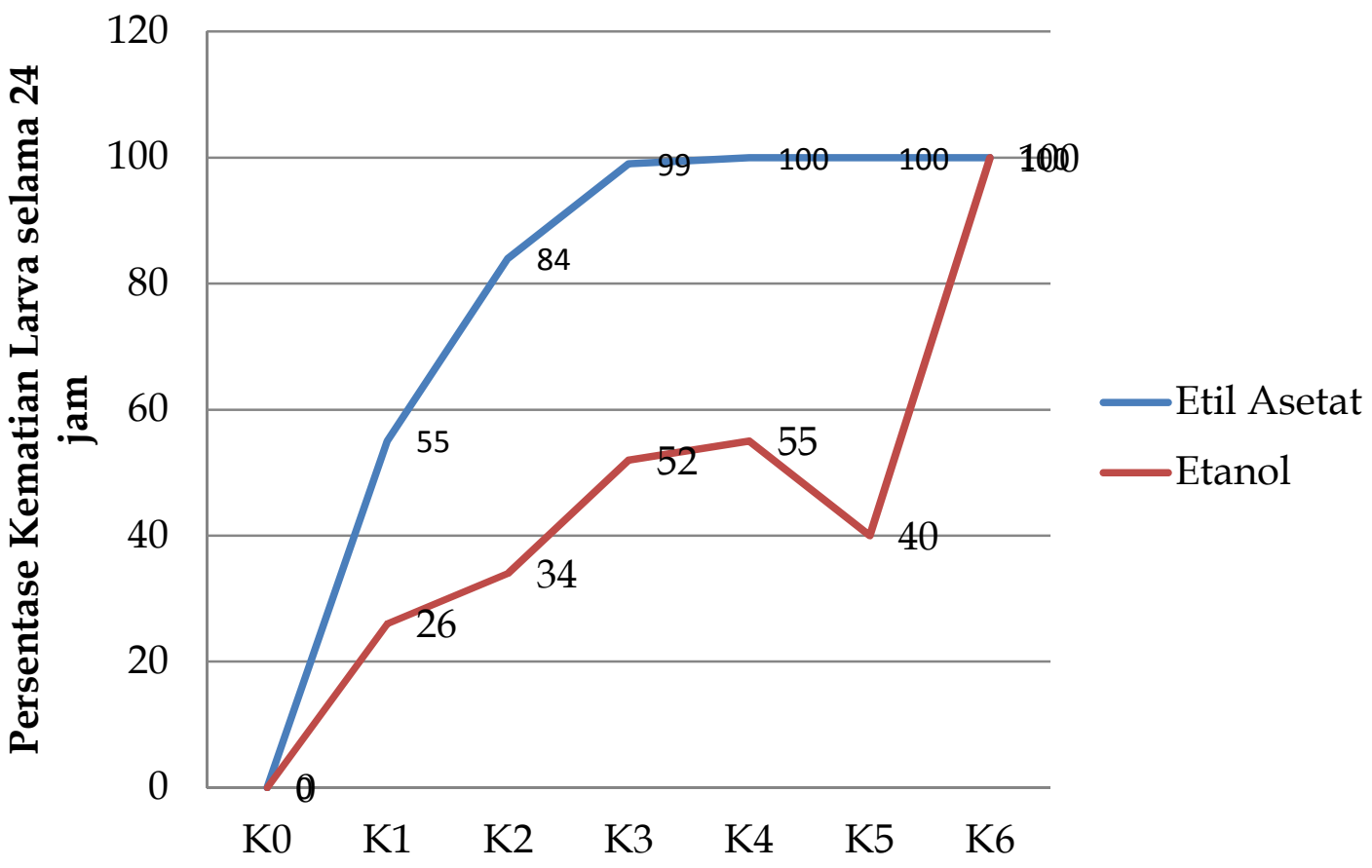

Gambar 1. Grafik persentase mortalitas A. aegypti selama perlakuan menggunakan ekstrak etanol dan etil asetat 
Berdasarkan grafik diatas dapat dilihat bahwa kematian larva A. aegypti pada kelompok kontrol (K0) adalah $0 \%$, pada kelompok kontrol positif menggunakan temephos 1\% (K6) adalah $100 \%$. Konsentrasi 1\% (K1) dari ekstrak etanol hanya mampu membunuh ratarata 7 ekor (26\%) bila dibandingkan dengan ekstrak etil asetat yaitu rata-rata 14 ekor (56\%). Konsentrasi 2\% (K2) dari ekstrak etanol hanya mampu membunuh rata-rata 8 ekor $(34 \%)$ bila dibandingkan dengan ekstrak etil asetat yaitu rata-rata 21 ekor (84\%). Konsentrasi 4\% (K3) dari ekstrak etanol hanya mampu membunuh rata-rata 13 ekor (52\%) bila dibandingkan dengan ekstrak etil asetat yaitu rata-rata 25 ekor (99\%). Konsentrasi 8\% (K4) dari ekstrak etanol hanya mampu membunuh ratarata 14 ekor (55\%) bila dibandingkan dengan ekstrak etil asetat rata-rata 25 ekor (100\%). Konsentrasi 16\% (K5) dari ekstrak etanol hanya mampu membunuh rata-rata 10 ekor (40\%) bila dibandingkan dengan ekstrak etil asetat rata-rata 25 ekor (100\%). Untuk melihat perbedaan kematian larva A. aegypti baik yang dipapar dengan temephos $1 \%$, ekstrak etanol maupun ekstrak etil asetat maka dilakukan uji One-way Anova yang dapat dilihat pada tabel 1 dibawah ini.

Tabel 1. Uji One-way Anova Kematian Larva A. aegypti

\begin{tabular}{lcccccc}
\hline Perlakuan & & $\begin{array}{c}\text { Sum of } \\
\text { Squares }\end{array}$ & df & $\begin{array}{c}\text { Mean } \\
\text { Square }\end{array}$ & F & Sig. \\
& Between Groups & 22787.429 & 6 & 3797.905 & & \\
Ekstrak & Within Groups & 2764.000 & 21 & 131.619 & 28.855 & .000 \\
Etanol & Total & 25551.429 & 27 & & & \\
Ekstrak Etil & Between Groups & 34131.429 & 6 & 5688.571 & & \\
Asetat & Within Groups & 1176.000 & 21 & 56.000 & 101.582 & .000 \\
& $\quad$ Total & 35307.429 & 27 & & & \\
\hline
\end{tabular}

Berdasarkan tabel diatas dapat disimpulkan bahwa terdapat perbedaan bermakna jumlah kematian larva $\mathrm{A}$. aegypti setelah pemberian abate bila dibandingkan dengan ekstrak daun maja menggunakan pelarut etanol maupun etil asetat dimana nilai $p=0,000$
( $\mathrm{p}<0,05)$, dengan nilai interval kepercayaan (99\%). Selanjutnya dilakukan uji Beda Nyata Terkecil (BNT) untuk melihat perbedaan antara kelompok perlakuan ekstrak daun maja dengan temephos $1 \%$, yang ditampilkan pada tabel 2 dan tabel 3 dibawah ini.

Tabel 2. Uji BNT mortalitas larva Aedes aegypti menggunakan ekstrak etanol

\begin{tabular}{lccccccc}
\hline Kelompok & K0 & K1 & K2 & K3 & K4 & K5 & K6 \\
\hline K0 & - & 26,000 & $34,000^{*}$ & $52,000^{*}$ & $55,000^{*}$ & $40,000^{*}$ & $100,000^{*}$ \\
K1 & - & - & 8,000 & 26,000 & $29,000^{*}$ & 14,000 & $74,000^{*}$ \\
K2 & - & - & - & 18,000 & 21,000 & 6,000 & $66,000^{*}$ \\
K3 & - & - & - & - & 3,000 & 12,000 & $48,000^{*}$ \\
K4 & - & - & - & - & - & 15,000 & $45,000^{*}$ \\
K5 & - & - & - & - & - & - & $60,000^{*}$ \\
K6 & - & - & - & - & - & - & - \\
\hline
\end{tabular}

Keterangan: * berbeda sangat bermakna $(p<0,01)$ 
Tabel 3. Uji BNT mortalitas Larva Aedes aegypti menggunakan ekstrak etil asetat

\begin{tabular}{lccccccc}
\hline Kelompok & K0 & K1 & K2 & K3 & K4 & K5 & K6 \\
\hline K0 & - & $55,000^{*}$ & $84,000^{*}$ & $99,000^{*}$ & $100,000^{*}$ & $100,000^{*}$ & $100,000^{*}$ \\
K1 & - & - & 8,000 & 44,000 & $45,000^{*}$ & $45,000^{*}$ & $45,000^{*}$ \\
K2 & - & - & - & 18,000 & 21,000 & 6,000 & $66,000^{*}$ \\
K3 & - & - & - & - & 3,000 & 12,000 & $48,000^{*}$ \\
K4 & - & - & - & - & - & 15,000 & $45,000^{*}$ \\
K5 & - & - & - & - & - & - & $60,000^{*}$ \\
K6 & - & - & - & - & - & - & - \\
\hline
\end{tabular}

Keterangan: * berbeda sangat bermakna $(p<0,01)$

Berdasarkan analisa probit, nilai LC50 dan LC90 dari ekstrak etanol yaitu $4,12 \%$ dan 10,82\%. Sedangkan nilai LC50 dan LC90 dari ekstrak etil asetat yaitu 2,03\% dan 3,04\%.

\section{PEMBAHASAN}

Bahan alam yang berasal dari tanaman saat ini sangat diperlukan untuk memutus rantai penularan DBD. Ekstrak daun Millingtonia hortensis sangat efektif terhadap larva Aedes aegypti, Anopheles stepensi dan Culex quinquefasciatus (Kaushik \& Saini, 2008). Ekstrak Balanites aegyptica L (Simaroubaceae), Nyctanthes arbortristis L (Oleaceae) dan Plumbago zeylanica L (Plumbaginaceae) menggunakan pelarut diklorometan dilaporkan sangat efektif membunuh larva dari Aedes aegypti dan Anopheles stepensi (Patil, Patil, Salunkhe, \& Salunke 2010). Daun maja (Aegle marmelos) merupakan tanaman obat yang berasal dari India. Pohon maja memiliki batang dengan cabang berduri dan daun berwarna hijau yang terdiri dari tiga sampai lima selebaran oval, runcing dan dangkal bergigi, panjang 4$10 \mathrm{~cm}$, lebar 2-5 cm, terminal dengan tangkai daun panjang (S Dhankar et al., 2011). Semua bagian dari tanaman maja telah digunakan sebagai obat tradisional sejak dulu misalnya untuk mengobati batuk, pilek, sakit tenggorokan, tonsillitis, bronchitis, kongesti dada, demam intermitten, penyakit usus, kontrol kesuburan, pengobatan setelah anak lahir dan sebagai racun ikan. Tanaman ini dikenal dengan nama "Maja" atau "Bael" merupakan tanaman perdu yang berasal dari India, termasuk dalam famili Rutaceae dan biasa digunakan sebagai obat (Elango et al., 2009). Beberapa tanaman dari famili Rutaceae, Asteraceae, Cladophoraceae, Lamiaceae, Meliaceae, dan Oocystaceae, merupakan salah satu famili yang berpotensi sebagai agent yang dapat mengusir nyamuk (Kim \& Ahn 2017). Kandungan Limonoid yang terdapat dalam famili Rutaceae dan Meliaceae telah digunakan dalam membuat beberapa formulasi insektisida karena efek racunnya terhadap serangga (Akram et al., 2010). Selain itu secara farmakologi, diketahui bahwa daun maja memiliki aktivitas sebagai antikontraktilitas, antimikrofilaria, analgesik, antiinflamasi dan antipiretik, antiulkus, antikonvulsan, antidepresan, antifertilitas, antijamur, antibakteri, hepatoprotektor, dan aktivitas insektisida (Patkar Al N, Desai NV, Ranage AiA, Kalekar 2012). Aktivitas insektisida pada penelitian Nilesh et al., 2012, melaporkan bahwa minyak esensial dari daun maja dapat menurunkan infestasi serangga 
Callosobruchus chinensis dan Rhyzopertha dominica yang sering ditemukan pada bonggol kacang. Berdasarkan hasil penelitian diketahui bahwa ekstrak daun maja dengan pelarut etil asetat lebih efektif membunuh larva A. aegypti dengan nilai LC50 sebesar 2,030\% bila dibandingkan dengan ekstrak daun maja menggunakan pelarut etanol.

Hal yang berbeda ditemukan pada penelitian yang dilakukan oleh Manimegalai dan Annapoorani (2013) menggunakan ekstrak daun maja dengan pelarut kloroform dan etanol terhadap kematian larva Culex quinquefasciatus melaporkan bahwa ekstrak daun maja menggunakan pelarut etanol $100 \%$ lebih efektif membunuh larva Culex quinquefasciatus dalam 48 jam (Manimegalai \& Annapoorani 2013). Penelitian yang dilakukan oleh Dass et al., 2014, menggunakan daun maja terhadap larva instar II, III, dan pupa Culex quingquefasciatus didapatkan nilai LC50 masing-masing sebesar 91.52 ppm, 105.16 ppm, 151.43 ppm dan 203.78 ppm (Dass \& Mariappan 2014). Penelitian lain yang dilakukan oleh Rathy, et al., 2015, melaporkan bahwa tanaman seperti Phyllanthus emblica, Lantana camara, dan Aegle marmelos (daun) memiliki aktivitas sebagai larvasida dengan nilai LC50 berkisar 1.08-9.12 $\mathrm{mg} / \mathrm{ml}$ (Rathy, Sajith, \& Harilal 2015). Hal ini sesuai dengan penelitian yang dilakukan oleh (Kim \& Ahn 2017; Komalamisra, Trongtokit, Rongsriyam, \& Apiwathnasorn 2005) suatu tanaman dipertimbangkan sebagai larvasida efektif apabila memiliki nilai LC50 yaitu $100 \mathrm{mg} / 1$ < LC50 < $750 \mathrm{mg} / 1$. Diketahui terdapat beberapa senyawa yang kemungkinan bersifat toksik dari tanaman maja yaitu alkaloid, terpenoid dan tannin. Sedangkan daun maja mengandung $\gamma^{-}$ sitosterol, aegelin, lupeol, rutin, marmesinin, $\beta$-sitosterol, flavon, glikosida, oisopentenyl halfordiol, marmeline dan phenylethyl cinnamamides. Limonene (82.4\%) merupakan penyusun utama dari daun Aegle marmelos dan penanda karakteristik untuk identifikasi sampel minyak Aegle marmelos (Patel, Garach, Chakraborty, \& Kamath 2012). Selain itu cara kerja saponin dan alkaloid sebagai racun perut dan menghambat kerja enzim koliesterase pada larva, cara kerja flavonoid sebagai racun pernapasan dan polifenol sebagai racun perut sehingga menyebabkan kematian larva. Senyawa golongan steroid sitosterol dan stigma sterol yang merupakan salah satu senyawa yang ada di dalam daun maja ternyata memiliki aktivitas larvasida pada larva nyamuk A. aegypti, A.stephensi dan C.quinquefasciatus, nilai LC50 : 11,5; 3,5 dan 26,7 ppm (Ghosh, 2013).

\section{SIMPULAN}

Tanaman maja terutama daun maja merupakan salah satu tanaman herbal yang dapat dimanfaatkan sebagai larvasida alami menggantikan abate. Ekstrak daun maja menggunakan pelarut etil asetat mempunyai aktivitas larvasida yang lebih tinggi dari ekstrak daun maja dengan pelarut etanol. Nilai LC50 ekstrak etil asetat $=2,030 \%$ dan etanol $=4,118 \%$. Dapat dilakukan penelitian lanjutan menggunakan kromatografi kolom dan analisa GC-MS untuk mengetahui bahan aktif dari daun maja. 


\section{Ucapan terimakasih}

Rasa syukur dan terima kasih

kami ucapkan kepada Lembaga

Penelitian dan Pengabdian Masyarakat (LPPM) Universitas Kristen Krida Wacana yang telah mendanai penelitian ini. Rasa terima kasih kepada UKPHP IPB untuk sampel penelitian dan kepada laboratorium penelitian fakultas kedokteran Ukrida. Juga kepada semua yang telah membantu penelitian ini dari awal hingga akhir.

\section{KEPUSTAKAAN}

Akram W, Khan HAA, Hafeez F, Bilal H, Kim YK, \& Lee JJ 2010. Potential of citrus seed extracts against dengue fever mosquito, Aedes albopic tus (Skuse) (Culicidae: Diptera). Pakistan Journal of Botany, 42(5), 3343-3348.

Beidokhti MN, \& Prakash HS 2013. Antioxidant and anti-inflammatory potential of selected medicinal plants of Lamiaceae family. International Journal of Pharmacy and Pharmaceutical Sciences, 5(SUPPL.1), 100-104.

Benni, J, Suresha R, \& Jayanthi M 2011. Evaluation of the anti-inflammatory activity of Aegle marmelos (Bilwa) root. Indian Journal of Pharmacology, 43(4), 393. https://doi.org/10.4103/02537613.83108

Borah R, Kalita MC, Kar A, \& Talukdar AK 2010. Larvicidal efficacy of Toddalia asiatica (Linn.) Lam against two mosquito vectors Aedes aegypti and Culex quinquefasciatus. African Journal of Biotechnology, 9(17), 2527-2530. https://doi.org/10.5897/AJB09.1786.

Dass K, \& Mariappan P 2014. Larvicidal Activity of Aegle marmelos, Coleus aromaticus and Vitex negundo Leaf Extract Against Filarial Vector Culex quinquefasciatus. Turkish Journal of Agricultural and Natural Sciences, 1, 858862.
Elango G, Rahuman AA, Bagavan A, Kamaraj C, Zahir AA, \& Venkatesan C 2009. Laboratory study on larvicidal activity of indigenous plant extracts against Anopheles subpictus and Culex tritaeniorhynchus. Parasitology Research, 104(6), 1381-1388. https://doi.org/10.1007/ s00436-0091339-7.

Fahmi U 2010. Buletin Jendela Epidemiologi: Manajemen Demam Berdarrah Berbasis Wilayah. Pusat Data Dan Survailans Epidemiologi Kemenkes $R I$, https://doi.org/http://dx.doi.org/ISS N\%202442-7659.

Fatmawati I 2015. Efektivitas Buah Maja ( \$ HJOH ODUPHORV ( L .) Corr .) sebagai Bahan Pembersih Logam Besi. Jurnal Konservasi Cagar Budaya Borobudur, 9(1), 81-87.

Ghosh A 2013. Efficacy of phytosterol as mosquito larvicide. Asian Pacific Journal of Tropical Disease, 3(3), 252. https:/ / doi.org/10.1016/ s22221808(13)60050-x.

Hadi UK, Soviana S, \& Gunandini DD 2013. Aktivitas nokturnal vektor demam berdarah dengue di beberapa daerah di Indonesia. Jurnal Entomologi Indonesia, 9(1), 1-6. https://doi.org/10.5994/jei.9.1.1.

Kaushik R, \& Saini P 2008. Larvicidal activity of leaf extract of Millingtonia hortensis (Family: Bignoniaceae) against Anopheles stephensi, Culex quinquefasciatus and Aedes aegypti. Journal of Vector Borne Diseases, 45(1), 66-69.

Kemenkes RI 2017. Kemenkes Optimalkan Psn Cegah Dbd, 2-3.

Kim SIl, \& Ahn YJ 2017. Larvicidal activity of lignans and alkaloid identified in Zanthoxylum piperitum bark toward insecticide-susceptible and wild Culex pipiens pallens and Aedes aegypti. Parasites and Vectors, 10(1), 1-10. https://doi.org/10.1186/s13071-0172154-0.

Komalamisra N, Trongtokit Y, Rongsriyam Y, \& Apiwathnasorn C 2005. S 
OUTHEAST A SIAN J T ROP M ED P UBLIC H EALTH SCREENING FOR LARVICIDAL ACTIVITY IN SOME THAI, 36(6).

Manimegalai K, \& Annapoorani CA 2013. International Research Journal of Pharmaceutical and Applied Sciences ( IRJPAS ) AEGLE MARMELOS AS AN EFFECTIVE AGENT AGAINST THE FOURTH INSTAR LARVAE OF CULEX QUINQUEFASCIATUS ( DIPTERA : CULICIDAE ), 3(4), 64-68.

Ndione RD, Faye O, Ndiaye M, Dieye A, \& Marie J 2007. Toxic Effects of Neem Products ( Azadirachta indica A . Juss ) on Aedes aegypti Linnaeus 1762 Larvae. Journal of Biotechnology, 6(24), 2846-2854.

Patel AR, Garach D, Chakraborty M, \& Kamath JV 2012. Aegle marmelos (Linn.): A therapeutic boon for human health. International Journal of Research in Ayurveda and Pharmacy, 3(2), 159-163. Retrieved from http://www.embase.com/search/res ults?subaction=viewrecord $\&$ from $=\exp$ ort\&id=L365979824\%5Cnhttp:/ / sfx.u md.edu/hs?sid=EMBASE\&issn=22774 343\&id=doi:\&atitle=Aegle + marmelos + $\% 28 \mathrm{Linn} . \% 29 \% 3 \mathrm{~A}+\mathrm{A}+$ therapeutic + boo $\mathrm{n}+$ for + human + health\&stitle $=$ Intern.$+\mathrm{J}$. + Res.+Ayurveda+Pharm.\&t.

Patil SV, Patil CD, Salunkhe RB, \& Salunke, B. K. (2010). Larvicidal activities of six plants extracts against two mosquito species, Aedes aegypti and Anopheles stephensi. Tropical Biomedicine.

Patkar AlN, Desai NV, Ranage AiA, Kalekar KSr 2012. a Review on Aegle Marmelos: a Potential Medicinal Tree. International Research Journal of Pharmacy, 3(8), 86-91. Retrieved from www.irjponline.com.

Rathy MC, Sajith U, \& Harilal CC 2015. Larvicidal efficacy of medicinal plant extracts against the vector mosquito Aedes albopictus. International Journal of Mosquito Research, 2(2), 80-82.

Reddy VP, \& Urooj A 2013. Antioxidant properties and stability of aegle marmelos leaves extracts. Journal of Food Science and Technology, 50(1), 135140. https://doi.org/10.1007/s13197010-0221-z.

Reegan AD, Gandhi MR, Paulraj MG, \& Ignacimuthu S 2015. Ovicidal and Oviposition Deterrent Activities of Medicinal Plant Extracts Against Aedes aegypti L. and Culex quinquefasciatus Say Mosquitoes (Diptera: Culicidae). Osong Public Health and Research Perspectives, 6(1), 64-69. https://doi.org/10.1016/j.phrp.2014.0 8.009 .

Rueda LM 2008. Freshwater Animal Diversity Assessment. Freshwater Animal Diversity Assessment, (January 1970). https://doi.org/10.1007/978-14020-8259-7.

S Dhankhar eep, Ruhil S, Balhara M, Dhankhar S, \& Chhillar AK 2011. Aegle marmelos (Linn.) Correa: A potential source of Phytomedicine. Journal of Medicinal Plants Research, 5(9), 14971507. Retrieved from http://www.academicjournals.org/jo urnal/JMPR/articleabstract/0BA544C17458.

Sari MP, Susilowati RP, Parasitologi D, Medicine F, \& Christian KW nd. LARVACIDE EFFICATION TEST OF MAJA ( Aegle Marmelos ) LEAVES POWDER ON Aedes aegypti, (L), 194200.

WHO 2011. Comprehensive guidelines for prevention and control of dengue and dengue haemorrhagic fever. Revised and expanded edition. SEARO Technical. https://doi.org/10.1017/CBO9781107 415324.004 .

World Health Organization 2009. Preventive and control of dengue hemmorhagic fever. Dengue Guidelines for Diagnosis, Treatment, Prevention and Control, 160. https://doi.org/10.1590/S007402761992000700024. 